УДК 355.58

\title{
ПОВЫШЕНИЕ ИНФОРМИРОВАННОСТИ ОБУЧАЮЩИХСЯ О БЕЗОПАСНОМ ПОВЕДЕНИИ В СЛУЧАЕ СКУЛШУТИНГА
}

Бабичев Арсентий Юрьевич

ФГБОУ ВО «Саратовский национальный исследовательский государственный университет им. Н.Г. Чернышевского»

\begin{abstract}
Аннотация: В статье рассматривается осведомленность обучающихся о вооруженных нападениях нынешних или бывших учащихся на образовательную организацию, приводящих к гибели или ранению педагогов, обучающихся, рабочего персонала. В работе приводятся результаты анкетирования, свидетельствующие о том, что не все респонденты готовы применить правила безопасного поведения в подобных ситуациях. Поэтому в статье предлагается программа, включающая ряд мероприятий, направленных на формирование готовности у учащихся к применению правил безопасного поведения в случае вооруженного нападения на образовательную организацию

Ключевые слова: Обучающиеся, образовательная организация, вооруженное нападение, скулшутинг, безопасное поведение.
\end{abstract}

\section{RAISING STUDENT AWARENESS OF SAFE BEHAVIOR IN SITUATION OF SCHOOLSHOOTING}

\section{Babichev Arsenty Yurievich}

\begin{abstract}
The paper addresses the problem of student awareness of armed attacks of current and former students on educational establishments, causing deaths or injuries of teachers, students and staff. The paper includes questionnarie results showing that not all students are ready to apply the rules of safe behavior in such situations. That's why we offer the program that comprises a set of events aimed at developing student readiness to apply the rules of safe behavior in situations of armed attacks on educational establishments.

Key words: Students, educational establishment, armed attack, schoolshooting, safe behavior.
\end{abstract}


Актуальность исследования. Вооруженные нападения учащихся на образовательные организации происходят все чаще и чаще в различных уголках нашей страны и становятся актуальной проблемой обеспечения безопасности обучающихся. Мотивы нападений банальны: недостаток внимания и любви в семье, травля, безразличие, жестокое обращение со стороны учителей и учащихся. Психологически загнанные в угол учащиеся идут на все, лишь бы их услышали и поняли.

Такие нападения предполагают применение насилия на территории учебного заведения и часто приводят к массовым убийствам. В США это явление называют стрельбой школьников или стрельбой в школах (англ. schoolshooting), поскольку при нападении чаще всего применяется огнестрельное оружие [1]. Совершается скулшутинг нынешними или бывшими учащимися данного учебного заведения, а пострадавшими становятся педагоги, обучающиеся и рабочий персонал. В России нападения на учащихся и педагогов совершаются в основном с использованием холодного оружия, поскольку ребенку легче достать нож, чем огнестрельное оружие [2, с. 63].

Образовательные организации сначала не были готовы к решению данной проблемы, но со временем стала проводиться работа по профилактике жестокого обращения с детьми и формированию у учащихся и педагогов безопасного поведения в случае скулшутинга.

Поэтому целью нашего исследования стало выявление степени информированности обучающихся о правилах безопасного поведения в случае вооруженного нападения и поиск путей ее повышения.

Объект исследования - учебно-воспитательный процесс в образовательной организации.

Предмет исследования - повышение информированности обучающихся о безопасном поведении в случае скулшутинга.

Meтоды исследования: анализ, синтез и обобщение данных педагогической, научной, методической литературы по проблеме исследования; планирование и разработка программы исследования; анкетирование; количественный и качественный анализ результатов исследования; математикостатистические методы обработки полученных данных.

Результать исследования. Для выявления информированности обучающихся о вооруженных нападениях на образовательную организацию нами была разработана анкета, включающая 10 вопросов: 
1. Слышали ли Вы когда-нибудь о вооруженных нападениях в образовательных организациях?

2. Встречались ли Вы с таким явлением?

3. О каких случаях вооруженного нападения на образовательную организацию Вы знаете?

4. Как Вы считаете, почему учащиеся совершают вооруженные нападения на учителей, учащихся?

5. Как Вы считаете, можно ли предупредить вооруженное нападение на образовательную организацию,

6. Проводят ли с вами беседы о правилах поведения при вооруженном нападении на образовательную организацию?

7. Считаете ли Вы, что тема вооруженного нападения на образовательную организацию является актуальной и ей нужно больше уделять внимания?

8. Знаете ли вы правила безопасного поведения в случае вооруженного нападения?

9. Готовы ли Вы придерживаться правил безопасного поведения для учащихся и педагогов в случае вооруженного нападения?

10. Готовы ли Вы принимать участие в проведении различных мероприятий по формированию навыков безопасного поведения в случае вооруженного нападения на образовательную организацию?

В исследовании принимали участие учащиеся 8-9 классов МОУ «Средняя общеобразовательная школа № 9 имени П.А. Столыпина г. Балашова Саратовской области» в количестве 20 человек. В данной образовательной органиизации проводится большая работа по профилактике скулшутинга и формированию безопасного поведения во время нападения.

Для сравнения мы провели анкетирование среди студентов психологопедагогического факультета, поступивших на первый курс профиля «Физическая культура. Безопасность жизнедеятельности» Балашовского института (филиала) ФГБОУ ВО «Саратовский национальный исследовательский государственный университет имени Н. Г. Чернышевского». Студенты, в количестве 20 человек, являются выпускниками различных школ Саратовской области. Поскольку студенты только приступили к занятиям, то мы можем оценить те знания, которые они получили в школе.

Результаты анкетирования показали, что все обучающиеся слышали о вооруженных нападениях на образовательные организации, но не встречались с 
таким явлением. Отвечая на третий вопрос, 80 \% учащихся назвали случай в Политехническом колледже в г. Керчь, а $20 \%$ вспомнили вооруженное нападение на школу № 127 в г. Пермь. В тоже время $90 \%$ студентов назвали случай в Беслане, хотя там школу захватили террористы, 10 \% вспомнили нападение в г. Колумбайн. штате Колорадо. По-видимому, студенты не видят разницы между этими нападениями. В случае скулшутинга трагедия заключается в том, что совершают эти ужасные нападения не террористы, не бандиты, а учащиеся этих же учебных заведений. Те, с кем пострадавшие были знакомы, часто общались, не ожидали от них ничего плохо, опасного.

Учащиеся считают, что наиболее распространёнными причинами нападения обучающихся на образовательные учреждения являются нарушение психического здоровья, проблемы в семье и жестокое обращение со стороны одноклассников и педагогов, травля в школе. Менее распространённой причиной стало пагубное влияние Интернета, особенно компьютерных игрстрелялок. Напротив, студенты считают, что наиболее распространёнными причинами таких нападений являются жестокое обращение со стороны педагогов, одноклассников, травля в школе, нарушения психического здоровья, проблемы в семье, подражание «стрелкам». Никто не указал, что причиной может быть пагубное влияние социальных сетей, компьютерных игр.

Отвечая на вопрос: «Как Вы считаете, можно ли предупредить вооруженное нападение на образовательную организацию?», мнения респондентов разделились. Большинство учащихся (60\%), считают, что это невозможно, 20 \% полагают, что если бы кто-то вовремя обратил внимание на ребенка, пытающегося получить помощь, то трагедия бы не произошла, остальные $(20 \%)$ затруднились ответить. Ответы студентов очень отличаются от ответов учащихся. Большинство студентов (90\%), считают, что это возможно, 10 \% полагают, что невозможно. По-видимому, это объясняется тем, что основной причиной нападения они считают жестокое обращение, которое можно предотвратить, а учащиеся - нарушения психического здоровья, в частности психопатии, неподдающиеся коррекции.

На шестой и седьмой вопросы все учащиеся ответили утвердительно, а мнения студентов разошлись. На шестой вопрос: «Проводили ли с вами беседы о правилах поведения при вооруженном нападении на образовательную организацию?» $80 \%$ ответили утвердительно, а $20 \%$ - отрицательно. В тоже время, $20 \%$ студентов не считают, что тема вооруженного нападения на 
образовательную организацию является актуальной и ей нужно больше уделять внимания?

Ответы учащихся на восьмой вопрос свидетельствуют о том, что они знают правила поведения в случае вооруженного нападения на образовательную организацию. Ответы студентов на восьмой вопрос свидетельствуют о том, что 80 \% осведомлены о правилах поведения в случае вооруженного нападения на образовательную организацию, $10 \%$ - не знают правила, а еще $10 \%$ затруднились с ответом. Затем респондентов попросили письменно перечислить правила безопасного поведения в случае скулшутинга. Однако и студенты, и учащиеся называют в основном правила поведения при захвате здания террористами, которые совершают такое деяние с определенной целью и выдвигают ряд требований. Дело в том, что тема терроризма подробно рассматривается в курсе «Основ безопасности жизнедеятельности». Эти правила несколько отличаются от правил безопасного поведения при скулшутинге. Тема вооруженного нападения учащихся на образовательную организацию в учебнике «Основы безопасности жизнедеятельности» не рассматривается. Учащиеся получают знания по данной проблеме только во внеурочной деятельности.

Однако на вопрос: «Готовы ли Вы придерживаться правил безопасного поведения для учащихся и педагогов в случае |вооруженного нападения?» утвердительно ответили $60 \%$. учащихся. Остальные ответили, что не готовы. Удивление вызвали ответы студентов. Все респонденты утвердительно ответили на этот вопрос, хотя $20 \%$ студентов не смогли их назвать.

На вопрос: «Готовы ли Вы принимать участие в проведении различных мероприятий по формированию навыков безопасного поведения в случае вооруженного нападения на образовательную организацию?» $100 \%$ респондентов ответили утвердительно.

Таким образом, результаты анкетирования выявили необходимость введения в учебную дисциплину «Основы безопасности жизнедеятельности» темы «Безопасное поведение в случае скулшутинга», а также проведение серии внеклассных мероприятий по профилактике скулшутинга. Поскольку результаты анкетирования свидетельствуют о том, что далеко не во всех школах ведется работа по профилактике скулшутинга и формированию у учащихся безопасного поведения при нападении, такую работу в обязательном порядке необходимо проводить во всех учебных заведениях. 
На основании полученных данных нами была разработана и частично апробирована программа «Безопасное поведение учащихся в случае вооруженного нападении на образовательную организацию». Цель программы мероприятий: совершенствовать систему воспитания у обучающихся ответственности за свою жизнь и умения грамотно действовать в случаях скулшутинга. Сроки реализации программы - в течение учебного года. Всего в программу включены 9 мероприятий. План предлагаемых мероприятий представлен в таблице.

Таблица

Тематический план программы «Безопасное поведение учащихся в случае вооруженного нападении на образовательную организацию»

\begin{tabular}{|c|c|c|c|}
\hline № & Название темы & Форма организации & $\begin{array}{l}\text { Количество } \\
\text { часов }\end{array}$ \\
\hline 1 & $\begin{array}{l}\text { История возникновения и статистика } \\
\text { скулшутинга. }\end{array}$ & Лекция-беседа & 1 \\
\hline 2 & $\begin{array}{l}\text { Уголовная ответственность обучающихся за } \\
\text { вооруженное нападение на образовательную } \\
\text { организацию. }\end{array}$ & $\begin{array}{c}\text { Беседа со } \\
\text { специалистом }\end{array}$ & 1 \\
\hline 3 & $\begin{array}{l}\text { Профилактика вооруженного нападения } \\
\text { обучающихся в образовательных } \\
\text { организациях . }\end{array}$ & Круглый стол & 1 \\
\hline 4 & $\begin{array}{l}\text { Причины вооруженных нападений учащихся } \\
\text { на образовательную организацию. }\end{array}$ & Беседа с психологом & 1 \\
\hline 5 & Как правильно себя вести при нападении & Практическое занятие & 1 \\
\hline 6 & $\begin{array}{l}\text { Возможно ли предупредить вооруженное } \\
\text { нападение учащихся на образовательную } \\
\text { организацию? }\end{array}$ & Дискуссия & 1 \\
\hline 7 & Оказание первой помощи пострадавшим & Практическое занятие & 1 \\
\hline 8 & $\begin{array}{l}\text { Разработка памятки для обучающихся «Как } \\
\text { предупредить нападение учащихся на } \\
\text { образовательную организацию?» }\end{array}$ & Практическое занятие & 1 \\
\hline 9 & $\begin{array}{l}\text { Итоговое занятие. Составление и обсуждение } \\
\text { резюме. }\end{array}$ & Практическое занятие & 1 \\
\hline
\end{tabular}

В результате внедрения программы ожидаются следующие результаты:

1. Умение анализировать и систематизировать факты, изложенные в методических и научных публикациях, по теме вооруженных нападений на образовательные организации.

2. Умение замечать предупреждающие признаки вооруженного нападения. 
3. Усвоение правил безопасного поведения в ситуациях скулшутинга.

4. Готовность применить правила безопасного поведения в случае вооруженного нападения на образовательную организацию.

5. Умение грамотно и своевременно применять на практике приемы оказания первой помощи пострадавшим.

Действия должны быть доведены до автоматизма во время практических занятий в рамках дисциплины «Основы безопасности жизнедеятельности». Кроме того, с учащимися всех классов от мала до велика, и педагогами необходимо регулярно проводить тренинг безопасного поведения, чтобы в случае тревоги избежать паники и тем самым увеличить их шансы на спасение.

\section{Список литературы}

1. Скулшутинг и «Колумбайн» по-русски [Электронный ресурс]/Режим доступа: https://www.ya-roditel.ru/parents/base/experts/skulshuting-i-kolumbayn-porusski/

2. Давыдов Д.Г., Хломов К.Д. Массовые убийства в образовательных учреждениях: механизмы, причины, профилактика // Национальный психологический журнал. - 2018. - № 4 (32). - С. 62-76. 